\title{
Assessing the Bacteriological Quality of Drinking Water from Sources to Household Water Samples of the Rural Communities of Dire Dawa Administrative Council, Eastern Ethiopia
}

\author{
Desalegn Amenu ${ }^{1^{*}}$, Sissay Menkir ${ }^{2}$ and Tesfaye Gobena ${ }^{3}$ \\ ${ }^{1}$ College of Natural \& Computational Science, Wollega University, Post Box No: 395, Nekemte, Ethiopia \\ ${ }^{2}$ College of Natural \& Computational Science, Haramaya University, Post Box No: 337, Dire Dawa, Ethiopia \\ ${ }^{3}$ College of Health Science, Haramaya University, Post Box No: 337, Dire Dawa, Ethiopia
}

\begin{abstract}
In Ethiopia, access to improved water supply and sanitation was estimated at $38 \%$ and $12 \%$ respectively. Three- forth of the health problems of children in Ethiopia are communicable diseases due to polluted water and improper water handling practices. Thus, this study was conducted to assess the bacteriological quality of drinking water sources in Dire Dawa Surrounding area. The study was conducted from February 2011 to May 2011. A total of 90 water samples from different water sources (-protected and unprotected well; protected and unprotected spring; and tap water) and bacteriological water quality parameters were analyzed using the membrane filtration method. Water analysis demonstrated that all water sources in the study areas were contaminated with total coliforms, fecal coliform and parasites. The average counts of TC were in the range of $1.5-133.05 \mathrm{CFU} / 100 \mathrm{ml}$ whereas the average counts of FC were found to be 0.34 $54 \mathrm{CFU} / 100 \mathrm{ml}$. In all samples, the TC, FC was above the recommended limit of WHOM for drinking water quality $(1-10 \mathrm{CFU} / 100 \mathrm{ml}$ for TC, 0CFU/100ml for FC. The fact that, about $83.34 \%$ of the water sample was positive for indicator bacteria shown that the three selected PA had risk of contamination in the three selected PAs had high risk of microbiological water quality parameters. High concentration of microbiological indicators in all water sources of this study area may demonstrated the presence of pathogenic organisms which constitute a threat to anyone consuming or in contact with these waters. This is due to lack of good water treatment, improper water handling practices and lack of the protection of the water sources. Consequently, protection of water sources accompanied by sanitation and hygiene promotion programs can improve the water

Article Information Article History:

Received : 09-06-2013

Revised : 20-09-2013

Accepted : 22-09-2013

Keywords:
Dire Dawa
Fecal colifrom
Ethiopia
Total coliform
Water quality analysis
${ }^{*}$ Corresponding Author:
Desalegn Amenu
E-mail:
wadadesalegn@gmail.com
quality of rural water sources, where disinfection is not feasible.
\end{abstract}

\section{INTRODUCTION}

Water is one of the most important compounds that constitute the largest part of life. About $70 \%$ of the earth's surface is water and $3 \%$ of this is fresh water. So far, out of the $3 \%$ fresh water, $99 \%$ is found beneath the surface (Jarrett, 1995). The major water sources for use are surface water bodies such as rivers and lakes, and underground sources and pore spaces down the water table (Ring, 2003). Water derived from these sources is not necessarily pure since it contains dissolved inorganic and organic substances, living organisms (viruses, bacteria, parasites, etc). For this reason, water intended for domestic uses should be free from toxic substances and microorganisms that are of health significance (WHO, 2005).

According to WHO (2003), more than $80 \%$ of the human diseases in the world are caused by unsafe water supply and due to inadequate environmental sanitation practices. One billion people lack access to safe water, while 2.4 billion people have inadequate sanitation. The latter has an impact on individuals, households, communities and countries. In a situation where there is no clean water and 


\section{Desalegn Amenu et al.,}

proper sanitation; millions of people would suffer from devastating diseases and millions of children would die due to water borne diseases (Hoffman, 2003).

Protection of water sources from contamination is the first line of defense against water borne disease. Because of the essential role water plays in supporting human life, it has great potential for transmitting a wide variety of disease and illnesses if contaminated. Source protection almost consistently is the best method of ensuring safe drinking water (Richards, 1996).

In rural areas and villages of Ethiopia, water for human consumption, drinking, washing (bathing, laundry), for preparation of food etc, is obtained from rivers, streams, shallow wells, springs, lakes, ponds, and rainfall. Unless water is made safe or treated for human consumption, it may be hazardous to health and transmit diseases. The main contaminants of these water sources are from human excreta because of open field defecation practices, animal waste and effluent from sewage system. Thus, the majority of rural communities use water from contaminated or doubtful sources, which expose the people to various water-borne diseases (MWR, FDRE, 2004).

Different types of pathogens can contaminate water, food, air and other environmental media in many different ways. Measuring all of these pathogens routinely for determining presence or absence or acceptable concentration is not possible. This is due to the following reasons: the methods are not available to recover and measure all microbes, the methods are available for only some selected microbes and not applicable for others; they are technically demanding, some methods are slow to produce results and their costs are high and it's impossible to enumerate all pathogenic microorganisms. Therefore, measuring something other than a pathogen that is indicative of contamination predicts the presence of pathogen and estimates human health risks. In addition, these indicators can tell whether the water is safe or not. So by using indicators the water quality can be assessed. The most applicable and recommendable indicator bacteria are fecal coliform and total coliform (Mark, 2006).

The use of indicator organisms, in particular the coliform group, as a means of assessing the potential presence of water-borne pathogens has been of paramount importance in protecting public health. The principle of the detection of selected bacteria that are indicative of either contamination or deterioration of water quality has been the foundation upon which protection of public health
Sci. Technol. Arts Res. J., July-Sep 2013, 2(3): 126-133

from water-borne diseases has been developed (Barrell et al., 2000).

Ethiopia is one of the developing countries where only $52 \%$ and $28 \%$ of its population have access to safe water and sanitation coverage, respectively (MoWR, 2007). For this reason, $60-80 \%$ of the population suffers from water-borne and waterrelated diseases $(\mathrm{MOH}, 2007)$. This burdens the country with enormous financial and social costs to take care of such a huge number of people suffering from these debilitating infections.

Some report showed that water sources and distribution systems of towns and rural communities alike have serious water quality problems. Assessment of bacteriological and physico-chemical qualities of urban source water and tap water distribution systems Ziway town (Kassahun, 2008), Bahir Dar town (Getnet,2008), Nazareth (Adama) town (Temesgen, 2009) showed contaminations of water by indicator bacteria such as total coliforms, faecal coliforms and/or faecal streptococci.

Similarly, underground water sources (hand dug wells) from rural areas in Menge District, Benishangul Gumuz region (Mebratu, 2007), and protected springs and hand pumped wells in Werebabo District, South Wello (Atnafu, 2006) indicated that $60-100 \%$ of the water samples were positive for total coliforms and faecal coliforms. This shows that the provision of safe water through extraction of water from deep underground and protected water sources from relatively less contaminated rural areas was not even immune from contamination.

All these findings give conclusive evidence that water quality problems are rampant both with smallscale and large-scale water delivery systems in the country. This would pose high health risks to users unless prompt intervention is undertaken. This, therefore, necessitates the evaluation and putting in place of sustainable monitoring system to determine the water quality status of municipal and rural water distribution systems.

As the previous study conducted on the prevalence of parasitic infections among children in Dire Dawa surrounding areas revealed that, safe water supply was not available or sufficient, so people were reverting to unhygienic and unsafe sources of water (Dawit, 2006). There is also improper household water storage and handling practices in all the villages. All the above-mentioned problems can lead to water related diseases if no intervention is made to solve water contamination in most rural areas of the communities (Dawit, 2006). 


\section{Desalegn Amenu et al.,}

The World Health Organization Microbiological Guidelines (2004) and Federal Democratic Republic of Ethiopia, Ministry of Water Resources (2002) for drinking water recommend zero total coliform and thermolerant/fecal coliform $/ 100 \mathrm{ml}$ of water.

Therefore, this study was used to evaluate the water quality based on two bacterial indicators of drinking water quality (total coliform, and thermolerant /fecal coliform) from different water sources (springs (unprotected and protected), wells (unprotected and protected) and tap water) and the water handling practices among the household in Dire Dawa Administrative Council.

There was no previous study conducted in this study area regarding to water quality assessment. The study conducted by Dawit (2006) was carried out on the prevalence of parasitic infection among children. Therefore, this study was conducted to initiate and fill the gap related to water quality of the rural communities. The findings of this study will provide baseline information about water quality for stakeholders for further work and intervention.

\section{MATERIALS AND METHODS}

\section{Description of The Study Areas}

The present study was conducted between February and May, 2011 in three purposively selected Peasant Associations (PA) named Legedini, Adada and Legebira, which are found in Dire-Dawa Administrative Council: (Figure 1). The Dire-Dawa town is located in Eastern parts of Ethiopia, which is $508 \mathrm{~km}$ away from Addis Ababa, capital city of Ethiopia.

All the three areas receive an average monthly rainfall of $55.71 \mathrm{~mm}$ and have bimodal pattern; the big rains occur from July to September, and the small rains from March to April. The monthly average maximum and minimum temperatures are $32.4^{\circ} \mathrm{C}$ and $19.1^{\circ} \mathrm{C}$, respectively and the mean annual relative humidity is $48.2 \%$ (NMSA, 2010). Legedini is located $28 \mathrm{~km}$ east of Dire-Dawa City, at $09^{\circ} 37^{\prime \prime} 57^{\prime} .3 \mathrm{~N}$ latitude and $042^{\circ} 02^{\prime \prime} 44^{\prime} \mathrm{E}$ longitude and an altitude of $1100-1600 \mathrm{~m}$ a.s.l. (Figure 1). The area has nine villages with a total population of 4500-5000. Adada is located $18 \mathrm{~km}$ east of DireDawa city. Geographically the area is located at $09^{\circ} 32^{\prime \prime} 53^{\prime} .6 \mathrm{~N}$ latitude and $41^{\circ} 566^{\prime \prime} 23^{\prime} .7 \mathrm{E}$ longitude and an altitude of $1506 \mathrm{~m}$ a.s.l. The area has 15 villages with a total population of 14,000 . Geographically; Legebira is located at $09^{0} 31^{\prime \prime} 23^{\prime} .4$ $\mathrm{N}$ latitude and $41^{\circ} 57^{\prime \prime} 16^{\prime} .5 \mathrm{E}$ longitude with an altitude of $1646 \mathrm{~m}$ a.s.l. that is at $15 \mathrm{~km}$ east of DireDawa city. The area has 6 villages with a total population of 2500-3500 (CSA, 2006; NMSA, 2010).
Sci. Technol. Arts Res. J., July-Sep 2013, 2(3): 126-133

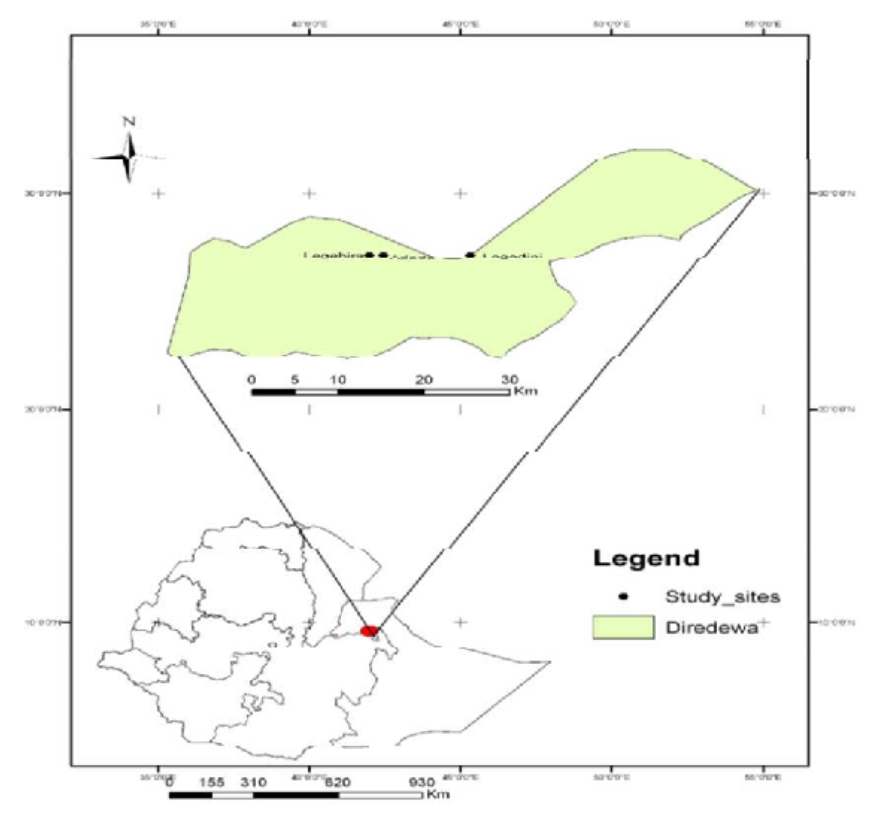

Figure 1: Map of Study Area showing the location of sampling sites, sources (Dawit, 2006).

Farmers in this study area are engaged in croplivestock mixed agriculture and they are not food self-sufficient and most of the time they are dependent on donation from government and other donor organizations (Dawit, 2006). The major crops cultivated by the farmers are maize and sorghum. The livestock owned by the people are mainly camels, cows, donkeys, oxen, goats and sheep. The above mentioned author further reported that in each study sites some people uses water from protected sources such as springs, boreholes, deep and shallow protected well, hand-dug wells, and others use from unprotected water sources such as surface water, river, seepage, unprotected well. The common problems of the three study sites are inadequacy of clean drinking water, lack of water for agricultural and household activities and insufficient sanitary facilities. As a result, waterborne \& hygiene related diseases occur frequently (Dawit, 2006).

Table 1: Summary of water sources types and their sanitation condition in the study sites.

\begin{tabular}{lll}
\hline StudySite & Study Villages & Water Sources \\
\hline \multirow{4}{*}{ Legedini } & Ajo, Halo, Ido, Ido Bolo, & Unprotected \\
& Kora and Konya & water sources \\
& Selela, Hodo Sere, & Protected water \\
& Kore Chafe and Lalo & sources \\
& Awale, Gebro, Afuretu, & Unprotected \\
& Hamesa and Gudora & water sources \\
Adada & Huri, Negeye, Berento, & Protected water \\
& Elimo Bajje, Adami, & sources \\
& Kulu, Dema and Chore & Unprotected \\
& Bira, Horro, Ware and & water sources \\
Legebira & Rebena & Protected water \\
& Shenno and Abdure & sources \\
\hline
\end{tabular}


Desalegn Amenu et al.,

\section{The Study Design}

A cross-sectional survey was conducted to determine the microbiological quality of water sources and to assess the households' water handling practices among the communities in the surrounding areas of Dire Dawa Town. The design also includes laboratory investigation which was carried out by collecting water samples from different sources from February, 2011 to May 2011. The questionnaires survey were done to collect data related to the respondents' socio-demographic characteristics and their water handling practices. The questionnaires were pre-tested in a few selected households living outside of the present study area.

\section{Water Sample Collection}

Due to limitation of resources, only three areas, Legedini, Legebira and Adada that are located in DDAC were selected purposively for the present study. Simple random sampling technique was employed to select the sampling sites in each study area.

In each study area and water samples were collected from five types of water sources, viz., protected well, unprotected well, protected spring, unprotected spring and tap water. A total of 90 water samples were collected and analyzed during February and May, 2011. 400ml-600ml water samples were collected in sterilized glass bottles that were washed and rinsed thoroughly with nitric acid and distilled water. In each round of sampling, one sample was taken at the center and the other two samples from the two edges of each site. These water samples were transported to Dire Dawa water supply and sanitation laboratory for microbiological water quality analysis.

\section{Microbiological Water Analysis Procedures}

\section{Bacteriological Analysis}

The samples were analyzed for total coliform (TC) and faecal coliforms (FC) using the membrane filter technique as outlined by the APHA (1998). This technique involved filtering water through a membrane that retained total coliforms, fecal coliforms; incubating this membrane on a growth promoting medium and then counting the resultant TC and FC units (APHA 1998).

Each water sample was mixed thoroughly by shaking for a total 30 minutes. $100 \mathrm{ml}$ of the sample was placed on surface of a sterile membrane filter with pore size $0.450 .45 \mu \mathrm{m}$ placed on funnel unit of the membrane filter support assembly. The filtration was facilitated by applying a vacuum pump, and the assembly was rinsed by sterile dilute water(APHA, 1998).
Sci. Technol. Arts Res. J., July-Sep 2013, 2(3): 126-133

Up on completion of the filtration process, vacuum were disengaged, unlocked and using a sterile forceps funnel were removed and membrane were removed immediately and placed on Membrane Lauryl Sulphate broth with a rolling motion to avoid entrapment of air in Petri dishes. Finally, the cultures were incubated at $37^{\circ} \mathrm{C}$ for 18 to $24 \mathrm{hrs}$. Up on completion of incubation period, typical coliform colonies (yellow colour) were seen on the surface of membrane filter paper. All yellow colonies extending on the membrane were counted as TC with the aid of a magnifying lens and recorded as total coliform (APHA, 1998).

For fecal coliform count, the same procedure was followed and the medium used, but the incubation and temperature was at $44^{\circ} \mathrm{C}$ for 18$24 \mathrm{hrs}$. Up on completion of the incubation period, yellow colored colonies on the surface of the filter paper were counted as FC. Finally, the total coliform and fecal coliform per $100 \mathrm{ml}$ of sample were calculated.

\section{Quality Control}

The assessment of water handling practices of the households of the community was collected using pre-structured questionnaires. The completed questionnaire was checked every day during data collection for completeness, clarity and consistency. A few selected households living outside the present study area were re-interviewed to check for the consistency of data.

\section{Data Analysis}

At the end of this study, the results on microbiological water quality and the households' water handling practices were analyzed and compared against standards set by WHO (2004) and Federal Democratic Republic of Ethiopia, Ministry of Water Resource (FDRE, MoWR, 2002). Analysis of variance (ANOVA) at $5 \%$ level of significance was used to compare the quality of water among all sites. The results were analyzed using statistical analysis software (SAS) version 9.0 and SPSS version 12.0.

\section{RESULTS}

Bacteriological Quality of Drinking Water Sources

Bacteriological analysis of water samples from the five sources (protected spring, unprotected spring, protected well, unprotected well and household water) in three sites of Dire Dawa Rural Communities showed that all water sources from Adada, Legedini and Legebira PA were positive for total coliforms and faecal coliform in two rounds of triplicate sampling (Table 2).

The results showed that all water samples $(100 \%)$, from unprotected and protected well 
Desalegn Amenu et al.,

sources were positive for total coliform; whereas $83.34 \%$ of water of the protected and unprotected spring sources has been total coliform. The least number of total coliform positive water samples of $50 \%$ was detected from household water sample (Table 2).

The TC counts were ranging from $1.50 \pm 0.71 \mathrm{CFU} / 100 \mathrm{ml}$ to $133.67 \pm 21.25 \mathrm{CFU} / 100 \mathrm{ml}$ with the lowest and the highest range corresponding to TC counts from samples of Adada household water and Legedini unprotected well, respectively. The fact that Legedini $(133.67 \pm 21.25$
Sci. Technol. Arts Res. J., July-Sep 2013, 2(3): 126-133

CFU/100ml), Legebira $(110.34 \pm 27.43 C F U / 100 \mathrm{ml})$, and Adada $(81.34 \pm 8.07$ CFU $/ 100 \mathrm{ml})$ from unprotected well contained the highest TC counts reflects that there were high human activities (laundering and bathing activities) and unhygienic practices that leads to the contamination of the water sources (Table 2).

The patterns of TC counts showed that, the Legedini water sources were more polluted), followed by Legebira water sources whereas Adada water sources were the least compared to others.

Table: 2: Occurrence of indicator bacteria and Mean bacteriological counts $(100 / \mathrm{ml})$ of five types of water sources in Dire Dawa communities during February and May 2011.

\begin{tabular}{|c|c|c|c|c|c|c|}
\hline \multirow[b]{2}{*}{$\begin{array}{l}\text { Study } \\
\text { Sites }\end{array}$} & \multirow[b]{2}{*}{ Water sources } & \multicolumn{3}{|c|}{ Occurrences of indictor bacteria } & \multicolumn{2}{|c|}{ Mean bacteriological count } \\
\hline & & $\begin{array}{c}\text { No. of } \\
\text { sample } \\
\text { examined }\end{array}$ & \begin{tabular}{c|}
$\begin{array}{c}\text { Total } \\
\text { coliform }\end{array}$ \\
Frequency \%
\end{tabular} & $\begin{array}{c}\begin{array}{c}\text { Fecal } \\
\text { coliform }\end{array} \\
\text { Frequency } \%\end{array}$ & Total coliform & Fecal coliform \\
\hline \multirow{5}{*}{ Adada } & Unprotected well & 6 & $6(100 \%)$ & $6(100 \%)$ & $81.34 \pm 8.07 a$ & $33.33 \pm 8.80 \mathrm{ba}$ \\
\hline & Unprotected spring & 6 & $6(100 \%)$ & $6(100 \%)$ & $64.5 \pm 8.61 b$ & $21.16 \pm 6.2 a b c$ \\
\hline & Protected well & 6 & $5(83.34 \%)$ & $5(83.34 \%)$ & $67.83 \pm 14.00 \mathrm{ab}$ & $18 \pm 7.68 \mathrm{abc}$ \\
\hline & Protected spring & 6 & $5(83.34 \%)$ & $4(66.67 \%)$ & $59.17 \pm 6.66 \mathrm{~b}$ & $15.34 \pm 6.59 \mathrm{abc}$ \\
\hline & household water & 6 & $3(50 \%)$ & $2(33.34 \%)$ & $1.5 \pm 0.71 \mathrm{c}$ & $0.34 \pm 0.2 \mathrm{~d}$ \\
\hline \multirow{5}{*}{ Lagabira } & Unprotected well & 6 & $6(100 \%)$ & $6(100 \%)$ & $110.34 \pm 27.20 a$ & $51 \pm 11.9 a$ \\
\hline & Unprotected spring & 6 & $6(100 \%)$ & $6(100 \%)$ & $80 \pm 17.07 \mathrm{a}$ & $33.5 \pm 6.73 a b$ \\
\hline & Protected well & 6 & $6(100 \%)$ & $5(83.34 \%)$ & $100 \pm 14.34 a$ & $26.5 \pm 9.12 b$ \\
\hline & Protected spring & 6 & $6(100 \%)$ & $4(66.67 \%)$ & $79.34 \pm 10.11 \mathrm{a}$ & $29.67 \pm 9.15 b a$ \\
\hline & household water & 6 & $4(66.67 \%)$ & $3(50 \%)$ & $5.66 \pm 0.61 \mathrm{c}$ & $1.5 \pm 0.2 \mathrm{~d}$ \\
\hline \multirow{5}{*}{ Legedini } & Unprotected well & 6 & $6(100 \%)$ & $6(100 \%)$ & $133.67 \pm 21.25 a$ & $45.5 \pm 12.00 a b$ \\
\hline & Unprotected spring & 6 & $6(100 \%)$ & $6(100 \%)$ & $99.5 \pm 13.72 a b$ & $54.83 \pm 11.84 a$ \\
\hline & Protected well & 6 & $6(100 \%)$ & $6(100 \%)$ & $120.16 \pm 23.73 a b$ & $25.83 \pm 7.03 b$ \\
\hline & Protected spring & 6 & $6(100 \%)$ & $5(83.34 \%)$ & $90.5 \pm 13.79 a b$ & $26 \pm 9.05 b$ \\
\hline & household water & 6 & $4(66.67 \%)$ & $3(50 \%)$ & $4 \pm 0.50 c$ & $1 \pm 0.36 d$ \\
\hline
\end{tabular}

NB. Grade with the same letter is not show significance difference, while grade with different letter show significance difference.

Table 3: The degree of bacteriological contamination from 5 types of water sources in DDAC, 2011.

\begin{tabular}{|c|c|c|c|c|c|c|c|c|c|}
\hline \multirow{3}{*}{ 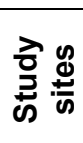 } & \multirow{3}{*}{ Water sources } & \multicolumn{4}{|c|}{ Total coliform CFU/100ml } & \multicolumn{4}{|c|}{ Thermotolerant/ Fecal coliform CFU/100ml } \\
\hline & & \multicolumn{4}{|c|}{ Sanitary infection score } & \multicolumn{4}{|c|}{ Sanitary infection score } \\
\hline & & 0 & $1-10$ & $11-100$ & $>100$ & 0 & $1-10$ & $11-100$ & $>100$ \\
\hline \multirow{5}{*}{$\begin{array}{l}\frac{\pi}{0} \\
\frac{\pi}{0} \\
\frac{\pi}{4}\end{array}$} & Unprotected well & $0(0 \%)$ & $0(0 \%)$ & $6(100 \%)$ & $0(0 \%)$ & $0(0 \%)$ & $0(0 \%)$ & $6(100 \%)$ & $0(0 \%)$ \\
\hline & Unprotected spring & $0(0 \%)$ & $0(0 \%)$ & $6(100 \%)$ & $0(0 \%)$ & $0(0 \%)$ & $2(33.34 \%)$ & $4(66.67 \%)$ & $0(0 \%)$ \\
\hline & Protected well & $1(16.67 \%)$ & $0(0 \%)$ & $5(83.34 \%)$ & $0(0 \%)$ & $1(16.67 \%)$ & $1(16.67 \%)$ & $4(66.67 \%)$ & $0(0 \%)$ \\
\hline & Protected spring & $1(16.67 \%)$ & $0(0 \%)$ & $5(83.34 \%)$ & $0(0 \%)$ & $2(33.34 \%)$ & $1(16.67 \%)$ & $1(16.67 \%)$ & $0(0 \%)$ \\
\hline & household water & $3(50 \%)$ & $3(50 \%)$ & $0(0 \%)$ & $0(0 \%)$ & $4(66.67 \%)$ & $2(33.34 \%)$ & $0(0 \%)$ & $0(0 \%)$ \\
\hline \multirow{5}{*}{ 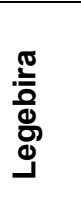 } & Unprotected well & $0(0 \%)$ & $0(0 \%)$ & $3(50 \%)$ & $3(50 \%)$ & $0(0 \%)$ & $0(0 \%)$ & $6(100 \%)$ & $0(0 \%)$ \\
\hline & Unprotected spring & $0(0 \%)$ & $0(0 \%)$ & $3(50 \%)$ & $3(50 \%)$ & $0(0 \%)$ & $3(50 \%)$ & $3(50 \%)$ & $0(0 \%)$ \\
\hline & Protected well & $0(0 \%)$ & $0(0 \%)$ & $3(50 \%)$ & $3(50 \%)$ & $1(16.67 \%)$ & $0(0 \%)$ & $5(83.34 \%)$ & $0(0 \%)$ \\
\hline & Protected spring & $0(0 \%)$ & $0(0 \%)$ & $4(66.67 \%)$ & $2(33.34 \%)$ & $2(33.34 \%)$ & $0(0 \%)$ & $4(66.67 \%)$ & $0(0 \%)$ \\
\hline & household water & $0(0 \%)$ & $6(1000 \%)$ & $0(0 \%)$ & $0(0 \%)$ & $0(0 \%)$ & $6(1000 \%)$ & $0(0 \%)$ & $0(0 \%)$ \\
\hline \multirow{5}{*}{ "ב } & Unprotected well & $0(0 \%)$ & $0(0 \%)$ & $2(33.34 \%)$ & $4(66.67 \%)$ & $0(0 \%)$ & $1(16.67 \%)$ & $5(83.34 \%)$ & $0(0 \%)$ \\
\hline & Unprotected spring & $0(0 \%)$ & $0(0 \%)$ & $1(16.67 \%)$ & $5(83.34 \%)$ & $0(0 \%)$ & $1(16.67 \%)$ & $5(83.34 \%)$ & $0(0 \%)$ \\
\hline & Protected well & $0(0 \%)$ & $0(0 \%)$ & $3(50 \%)$ & $3(50 \%)$ & $0(0 \%)$ & $0(0 \%)$ & $6(1000 \%)$ & $0(0 \%)$ \\
\hline & Protected spring & $0(0 \%)$ & $0(0 \%)$ & $3(50 \%)$ & $3(50 \%)$ & $0(0 \%)$ & $0(0 \%)$ & $6(1000 \%)$ & $0(0 \%)$ \\
\hline & household water & $0(0 \%)$ & $6(1000 \%)$ & $0(0 \%)$ & $0(0 \%)$ & $2(33.34 \%)$ & $4(66.67 \%)$ & $0(0 \%)$ & $0(0 \%)$ \\
\hline
\end{tabular}

Keys: OCFU/100ml=safe, 1-10CFU/100ml=reasonable quality, 11-100CFU/100ml=polluted and $>100 \mathrm{cfu} / 100 \mathrm{ml}=$ dangerous (WHO, 2004a, FDRE, WRM, 2002). 
Desalegn Amenu et al.,

\section{DISCUSSION}

In this study area, the degree of bacteriological water contamination was very high. The bacteriological counts in most sites were in dangerous range of pollution for drinking specially by TC and TTC/FC (11-100 CFU/100ml). None of the water sources were found to be safe for drinking except the tap water. Moreover, most of water samples taken from spring (unprotected and protected) and well (unprotected and protected) had very high pollution levels categorized under dangerous. While the samples from the household water had lower pollution levels, none of the other samples could be categorized under the very dangerous degree of pollution (Table 3 ).

With regards to thermotolerant (faecal) coliforms, all water samples $(100 \%)$ were found to contain thermotolerant (faecal) coliforms in the range of $0.34-54 \mathrm{CFU} / 100 \mathrm{ml}$ with significant variation at $(P<0.0001)$ (Annex III). The highest and lowest levels of thermotolerant (faecal) coliforms, i.e., 54 CFU $/ 100 \mathrm{ml}$ and $0.34 \mathrm{CFU} / 100 \mathrm{ml}$, were recorded from Legedini protected well and Adada household water, respectively. The high level of coliform count recorded in this study may be attributed to the high degree of contamination of the water sources due to unhygienic practices around and near water sources.

From all the study sites, the highest TTC/FC count was recorded from Legedini PAs followed by the lowest counts from Adada PA. The largest TTC/FC count $(54 \mathrm{CFU} / 100 \mathrm{ml})$ was recorded from Legedini protected well followed by $51 \mathrm{CFU} / 100 \mathrm{ml}$ and $33 \mathrm{CFU} / 100 \mathrm{ml}$ from water samples of Legebira and Adada (unprotected well), respectively. Therefore, all water sources except household water samples were polluted by TTC/FC.

All samples of the water sources in this study were contaminated with total coliforms. Except the water samples from the household water that had $50 \%$ contamination, all the others had $100 \%$ contamination with total coliforms. Out of these, $100 \%$ of the samples from unprotected well and protected well, $83.34 \%$ the sample from unprotected spring and protected spring had unacceptable levels of total coliforms according to the suggested criteria for drinking water sources (WHO, 2004a; FDRE, $\mathrm{MoH}, 2002)$. Likewise, all water sources were $100 \%$ contaminated with thermotolerant (faecal) coliforms, except the sample from tap water, which had only $50 \%$ of contamination level.

Similarly, $100 \%$ of the samples from unprotected well and protected well, $83.34 \%$ from unprotected and protected spring were contaminated by
Sci. Technol. Arts Res. J., July-Sep 2013, 2(3): 126-133

thermotolerant (faecal) coliforms. As the study conducted by Getnet (2008) from Bahir Dar town showed that $100 \%$ of the analyzed water samples from the source had a mean total coliform count of $35.5 \mathrm{CFU} / 100 \mathrm{ml}$ which is above the acceptable level recommended by WHO (2005). This is much lower than the present study. This difference may be due to the site selection, inadequate protection of water sources and unhygienic practices near the water sources (Richards, 1996).

According to the study conducted by Mengesha in North Gonder ,out of the seventy analyzed protected spring and protected well water samples, $71.43 \%$ and $28.6 \%$ had levels of total coliform (TC) and faecal coliform /thermotolerant (TTC/FC) count, respectively and the author also further demonstrated that, $50 \%$ of the samples had a coliform count of 180 and above $/ 100 \mathrm{ml}$ and the lowest coliform count was 13 coliform $/ 100 \mathrm{ml}$ (Mengesha et al., 2004), which was higher than the present study that was 133.65 coliform $/ 100 \mathrm{ml}$ and the lowest total coliform 1.50 coliforms $/ 100 \mathrm{ml}$.

In another study in South Wello, Ethiopia, Atnafu (2006) demonstrated that, $75 \%$ of the samples from protected springs were contaminated with total coliforms. This was less than the present study, where all water sources were contaminated with total coliform. In contrast, as the research conducted in Yubdo-Legebatu by Birhanu (2008) indicated that, all the water samples were contaminated by the total coliform in which the highest total colifrom was 1447.47 coliform/100ml and the lowest coliform was 193.8 coliform $/ 100 \mathrm{ml}$ and this was also much higher than the present study. This difference may be due to the lack of water sources protection in the case of YubdoLegebatu and not in case of Dire Dawa Rural Communities.

In harmony with the present study, results of monitoring six sampling stations in the Geum River in Korea showed average concentrations of total coliforms ranging from 1670 to $8510 \mathrm{cfu} / 100 \mathrm{ml}$ (Geonha et al., 2005). This was higher than the present study and the possible reasons for this variation may be due to the differences in dilution and sources of contaminants, water sources protection and unhygienic practices near the water sources (Richards, 1996).

Alternatively, as the research conducted in Debrezeit town (Desta, 2009 ) from all water source samples $(100 \%)$ were contaminated by TC to the range of $1-4$ coliform $/ 100 \mathrm{ml}$, but within the acceptable limit of $1-10$ coliform/100ml set by WHO (1997). In a similar study conducted on rural handdug pump well water from South Wello, Atnafu 
Desalegn Amenu et al.,

(2006) reported that $50 \%$ of the underground wells contain TC counts of $3.3 \mathrm{CFU} / 100 \mathrm{ml}$. This had lower range of total colifrom than present study, but the $(100 \%)$ of water samples contain total coliform. This indicates that the degree of risk factors for the contamination of water sources in Rural Communities of DDAC is tremendously increasing due to uncontrolled waste disposal and inadequate water treatment around the water sources (Tamiru, 2001).

ANOVA of total coliform concentration among all sources demonstrated that there was a significant difference $(P<0.001)$ in the average counts of TC between the water sampling sources and sites. Total coliforms in unprotected spring and unprotected well of the Legedini were significantly higher than in all other sources of all sites. Moreover, there is poor sanitation and unhygienic practices near the water sources. In addition drawing water is done using unclean cups and cans, while there is also open access for livestock and wildlife. All these factors might be possible reasons for the high concentrations in total coliforms in this study area. This result was supported by questionnaires survey on households' water handling practices.

Unprotected wells and unprotected springs demonstrated that $100 \%$ of the samples taken from both sources were contaminated by total coliform and fecal coliforms. In addition, analysis of the water samples from the protected spring and wells demonstrated that $100 \%$ of the water sources were contaminated by coliform. These results were supported by the research conducted by Mengasha in which analysis of protected springs confirmed that above $71.43 \%$, of the samples had indicator bacteria (Mengesha et al., 2004) this is lower than the present study conducted in different water sources of Dire Dawa Rural Communities

The variance analysis of Thermotolerant/fecal coliform concentrations among all sources showed that there was a highly significant difference $(P<0.001)$ in the average counts of TTC/FC among all water sites and sources.

Mean thermotolerant (fecal) coliform levels in unprotected well of Legebira were significantly higher than in all other sources and sites. Thermotolerant/Fecal coliforms are indicators of fecal contamination. Hence, categorizing the site in terms of risk to human health, the majority, above $(66.67 \%$ of sampled water sources in the study area were at high risk.

Bacteriological contamination of water from various sources is commonly due to the lacks of
Sci. Technol. Arts Res. J., July-Sep 2013, 2(3): 126-133

water treatment, good sanitation, good management of water sources, environmental sanitation etc. In South Australia, Esterman et al. (1984) surveyed 100 water samples finding $18 \%$ of the water sources with at least one unacceptable bacteriological result, but no significant difference between wells and springs was observed. In all cases there was no significance difference between unprotected sources and protected sources in the wells and in spring because, the wells and springs were not properly protected. The spring was not properly covered by stone masonry with one or two boxes and the well was not properly covered by stone masonry (WHO, 1983).

\section{CONCLUSION}

The microbiological quality of drinking water sources and water handling practices at household level in rural communities of Dire Dawa was conducted at the Dire Dawa Rural Communities water supply and sanitation laboratory.

The bacteriological results from this study were not harmony with the reference values set out by WHO (2004) and they were grossly polluted. Therefore, the bacteriological quality of drinking water sources in rural communities of Dire Dawa (Adada, Legedini and Legebira) did not meet national or international guidelines for drinking water that is set by WHO standard. The overall microbiological count (bacterial and parasitic) and water handling assessment among households indicated that the majority of water sources in rural communities of Dire Dawa (Adada, Legedini and Legebira) could be classified as more polluted, while some were at intermediate risk and very few water points had reasonable quality.

High counts of indicator organisms in all sampled water sources of the study areas suggested the presence of pathogenic organisms that constitute a threat to anyone consuming these water sources. The contamination of these water sources with pathogenic organisms due to the absence of fencing of water sources that could prevent the entrance of animals, livestock grazing nearby water sources, people's open area defecation, collecting of water with unclean jug, cups, agricultural activities nearby water sources, and lack of regular disinfection of the water reservoir. Future studies are needed to determine the seasonal variations in the contamination level of the water sources, to quantify pathogen loads in different water sources to develop risk-reducing water quality management systems. 
Desalegn Amenu et al.,

\section{REFERENCES}

American Public Health Associations (APHA), (1998). Standard Methods for the Examination of Water and Waste Water. American People Health Association, $20^{\text {th }}$ edn, Washington DC.

Atnafu, M. (2006). Assessment of Bacteriological Quality of Drinking Water Supply at the sources and Point of Use at Home in Worebabu District, South Wollo. M.Sc Thesis. Addis Ababa University, Addis Ababa. Pp. 34-57.

Barrell, R., Hunter, P.R and Nichols, G. (2000). Microbiological standards for water and their relationship to health risk. Communicable Disease and Public Health 3: 8-13.

Birhanu, M. (2008). Assessment of the contamination level of water and determines the major sources of contamination at water collection point in Yubdo Legebatu River, East Show, and Ethiopia. Addis Ababa. Pp. 34-65.

Central Statistical Authority of Dire Dawa Administrative Council (2006). Dire Dawa, Ethiopia.

Dawit, Ayalew. (2006). Association of Cryptosporidium Parvum, Giardia Lamblia and Entamoeba Histolytica/Dispar Infection with Drinking Water Sources among Children in Rural Part of Dire- Dawa. Addis Ababa, Ethiopia. Pp. 20-30.

Desta Kassa. (2009). Bacteriological \& Physicochemical Quality assessment of Drinking Water Supply from source to taps in Debrezeit town, Ethiopia. Addis Ababa University, Addis Ababa.M.Sc.Thesis Addis Ababa University, Ethiopia. Pp.50-60.

Federal Democratic Republic of Ethiopia, Ministry of Health (FDRE, MoH), (1997). Rapid assessment of drinking water quality in the Federal Republic of Ethiopia, country report. Federal Democratic Republic of Ethiopia, Ministry of Health Addis Ababa, Ethiopia.

Federal Democratic Republic of Ethiopia, Ministry of Health (FDRE, MoH), (2007). Rapid assessment of drinking water quality in the Federal Republic of Ethiopia, country report. Federal Democratic Republic of Ethiopia, Ministry of Health, Addis Ababa, Ethiopia.

Geonha, K., Euiso, T.C. and Dongryul, L. (2005). Diffuse and point pollution impacts on the pathogen indicator organism level in the Genum river, Korea. Science of the Total Environment 350: 94-105.

Getnet Kassahun (2008). Physico-chemical and Bacteriological Drinking Water Quality Assessment of Bahir Dar town water supply from source to yard connection (North- Western Ethiopia). M.Sc Thesis, Addis Ababa University, Addis Ababa.

Hoffman, A.R. (2003). Energy and Water, U.S. and Winrock International.1-33.

Jarrett, A. (1995). Water Management. Kendall/Hunt Publishing Company, USA.
Sci. Technol. Arts Res. J., July-Sep 2013, 2(3): 126-133

Kassahun Bedane. (2008). Assessment of Physicochemical and Bacteriological Quality of Drinking water in Central Rift Valley System, Ziway town, Oromia Regional state. M.Sc Thesis. Addis Ababa University, Addis Ababa.

Mebratu Jano. (2007). Assessment of Physicochemical and microbiological Quality of rural Drinking water supply at the source in Menge Woreda, Benshangul Gumuz Regional state, Ethiopia. M.Sc Thesis. Addis Ababa University, Addis Ababa.

Mark, D. (2006). Drinking water and health research: a look to the future in the United States and globally, accessed on October $12^{\text {th }}, 2006$.

Mengesha Admassu., Mamo Wubshet and Baye Gelaw, (2004). A survey of bacteriological quality of drinking water in North Gondar. Ethiopian Journal of Health Development 18(2): 113-135.

Richards, J.B. (1996). Drinking Water monitoring and surveillance. African Health 4:10.

Tamiru Alemayehu, (2001). The impact of uncontrolled waste disposal on surface water quality in Addis Ababa. SINET: Ethiopian Journal of Science 24(1): 93-104.

Temesgen Eliku. (2009). Assessment of Physicochemical and Bacteriological Quality of Drinking Water supply at sources and house hold in Adama town, Oromia Regional state, Ethiopia. M.Sc Thesis. Addis Ababa University, Addis Ababa.

United Nations Children's Fund and World Health Organization (WHO), (2008). Joint Monitoring Programmed for Water Supply and Sanitation. Meeting the MDG Drinking Water and Sanitation Target, A Mid-Term Assessment of Progress. New York, NY.

United States Environmental Protection Agency (USEPA), (2005). Method 1623: Cryptosporidium and Giardia in water by Filtration/IMS/FA. United States Environmental Protection Agency, Office of water.

World Health Organization (WHO), (2002). Water, Sanitation and Health. Managing water in the home: accelerated health gains from improved water supply. Geneva.

World Health Organization (WHO), (2003). Guidelines for drinking water quality, Vol.3. World Health Organizations, Switzerland, Geneva.

World Health Organization (WHO), (2004). Water, sanitation and hygiene links to health, facts and figures. Geneva.

World Health Organization (WHO) and UNICEF, (2006). Meeting the MDG drinking water and sanitation target: the urban and rural challenge of the decade. Geneva. 